\title{
THE EFFECT OF POTASSIUM DEFICIENCY ON THE FREE AMINO ACID PATTERN OF THE MUSCLE TISSUE OF PROTEIN- MAINTAINED FUNDULUS HETEROCLITUS ${ }^{1,2}$
}

\author{
DAVID P. HANLON ${ }^{3}$ \\ Department of Biochemistry, University of New Hampshire, Durham, New Hampshire
}

In this investigation the effect of a low potassium environment on the free amino acid pattern of the skeletal muscle tissue of the killifish, Fundulus heteroclitus, has been studied in an attempt to determine if the changes observed in the potassium-deficient rat (Eckel, Pope and Norris, 1954; Iacobellis, Muntwyler and Dodgen, 1956) could also be found in other members of the vertebrate subphylum. Apparently the rat, but not the dog (Iacobellis, Griffen and Muntwyler, 1957), is capable of replacing part of an intracellular loss of potassium ions with organic cations in the form of basic amino acids, provided a sufficient amount of protein is included in the diet. Amino acids which could serve to restore an intracellular cation-anion balance include lysine, arginine, and histidine. All three carry a net positive charge at body $\mathrm{pH}$. This study, therefore, was made to determine if an intracellular organic cation replacement occurs in potassium-deficient Fundulus and, if so, which basic amino acids are responsible for the replacement of the lost potassium.

\section{Methods}

Killifish (Fundulus heteroclitus) were trapped in the brackish water of the Oyster River near Durham early in August of 1958 and transported to the laboratory where they were placed in a large aquarium containing artificially prepared $50 \%$ sea water (salinity $=18$ parts per thousand). The formula followed was taken from the Marine Biological Laboratory at Woods Hole manual, "Formulae and Methods, IV," 1954. After a three-day period of adjustment, one-half of the animals was left in 50\% sea water to serve as controls, whereas the other half was placed in an adjacent aquarium also containing $50 \%$ artificial sea water but lacking potassium ions. Control and potassium-deficient animals were maintained on a diet of powdered, crude casein.

At the end of a two-week period animals were removed from each aquarium and their tissues prepared for paper chromatography. In order to obtain 10 grams of skeletal muscle tissue in each case it was necessary to sacrifice 7 control Fundulus and 8 potassium-deficient Fundulus. The fish were skinned and filleted. Ten grams of muscle were macerated in a Waring Blendor, using about $100 \mathrm{ml}$. of $95 \%$ ethanol. After 5 minutes of blending at a moderate speed the liquid was

${ }^{1}$ Published with the permission of the Director of the New Hampshire Agricultural Experiment Station, as Scientific Contribution No. 240.

${ }^{2}$ The author wishes to thank Dr. A. E. Teeri and Dr. D. Routley for their helpful suggestions in the preparation of this paper.

${ }^{3}$ Present address: Department of Zoology, University of Connecticut, Storrs, Connecticut. 
transferred to $50-\mathrm{ml}$. centrifuge tubes and centrifuged for 5 minutes at 3000 r.p.m. The centrifugate was removed (the precipitate consists chiefly of protein) and reduced in vacuo to a volume corresponding to $1 \mathrm{ml}$. per gm. of tissue extracted. Slight heat was applied to speed reduction. While awaiting use, the extract samples were kept in the refrigerator.

Two-dimensional ascending paper chromatography was employed to determine in a semi-quantitative manner the free amino acids present in the muscle tissue of the control and potassium-deficient Fundulus. Aliquots of $60 \mu 1$. were spotted on Whatman No. 1 filter paper sheets $\left(9^{\prime \prime}\right.$ by $\left.12^{\prime \prime}\right)$ and developed for 16 hours with a phenol-water (4:1) solvent. The chromatograms were dried at room temperature and developed for 16 hours in the second dimension with a lutidine-water $(2: 1)$ solvent. After drying, the amino acids were located by spraying the chromatograms with a $0.1 \%$ solution of ninhydrin in $95 \%$ ethanol. The Sakaguchi test for arginine and the Pauli test for histidine were also employed (Block, Durrum and Zweig, 1955). The location of lysine was confirmed on the ninhydrin-developed chromatograms by exposing them to hydrochloric acid fumes for one minute. The spot representing lysine turns a bright yellow (Szantai, 1957) which is stable for several days. Valine, leucine and threonine also turn yellow, but the color soon fades. This, taken in conjunction with the relative positions of the above-named acids on the two-dimensional chromatogram, makes any confusion of valine, leucine or threonine for lysine unlikely.

Total amino acid concentration was determined quantitatively as follows. Ten $\mu 1$. of the tissue fluid extracts were spotted on Whatman No. 1 filter paper. Also spotted on the filter paper were $10 \mu \mathrm{l}$. quantities of a standard solution containing $6 \mu \mathrm{gm}$. of amino acid per $\mu \mathrm{l}$. Since three amino acids, glycine, alanine and taurine, were found to be responsible for the bulk of the color observed on the ninhydrinsprayed chromatograms, the standard was prepared by dissolving $20 \mathrm{mg}$. each of these amino acids in $10 \mathrm{ml}$. of distilled water. It was felt desirable to use this type of standard to allow for differences in the absorption characteristics of the ninhydrin complexes. After application the spotted amino acid solutions were allowed to dry at room temperature, then were sprayed with a $0.5 \%$ solution of ninhydrin in $75 \%$ ethanol plus $0.5 \% 1 \mathrm{~N}$ sodium hydroxide. Kay, Harris and Entenman (1956) report that the presence of sodium hydroxide is essential for the development of color in the case of taurine, but otherwise has no effect. Curiously, the author found that sodium hydroxide had no such specific enhancing effect in the case of taurine, although a general increased color density was observed. The ninhydrin-treated filter paper was dried at room temperature and then heated at $60^{\circ} \mathrm{C}$. for 25 minutes. The colored areas were cut out and eluted with $5 \mathrm{ml}$. of a $75 \%$ ethanol solution containing $10 \mathrm{mg}$. of cupric sulfate $\left(\mathrm{CuSO}_{4} \cdot 5 \mathrm{H}_{2} \mathrm{O}\right)$ in $200 \mathrm{ml}$. of solution (Giri, Radhakrishnan and Vaidyanathan, 1952). Blanks were prepared by cutting out portions of filter paper equal in area to those supporting the colored complexes. Optical density of the colored solutions was read at $540 \mathrm{~m} \mu$ on a Bausch-Lomb "Spectronic 20."

Two-dimensional paper chromatography was used to determine the amount of lysine present in the muscle tissue of potassium-deficient and control Fundulus. Sixty- $\mu$ l. aliquots were used in the case of the potassium-deficient fish whereas $400 \mu \mathrm{l}$. were required in the case of the control animals, due to the very low con- 
centration of lysine in their tissues. Three to $5 \mu \mathrm{l}$. of an aqueous solution containing $6 \mathrm{mg}$. of lysine per $\mathrm{ml}$. of solution, serving as standards, were spotted and chromatographed. Chromatograms were developed using phenol-water (4:1) and lutidine-water $(2: 1)$ as solvents. After drying at room temperature the chromatograms were sprayed with ninhydrin as before. Apparently the spraying procedure is the most crucial point in the quantitative determination. Care should be taken to spray the chromatograms lightly and evenly on one side, allow them to dry, then repeat the operation on the other side. The chromatograms were heated, lysine spots cut out and eluted and optical density read as in the case of the determination of total amino acid concentration.

\section{Results}

Fifteen amino acids were found to be present in the extracts of the control and potassium-deficient animals. The same amino acids were present in both cases. Furthermore, it was found that (1) the total amino acid concentration

\section{TABLE I}

The total concentration of amino acids and the concentration of lysine in the skeletal muscle of control and potassium-deficient Fundulus heteroclitus

\begin{tabular}{l|c|c|c|c}
\hline \hline & \multicolumn{2}{|c|}{$\begin{array}{c}\text { Total concentration } \\
\text { (in mg./gm. of tissue) }\end{array}$} & \multicolumn{2}{|c}{$\begin{array}{c}\text { Lysine concentration } \\
\text { (in mg./gm. of tissue) }\end{array}$} \\
\cline { 2 - 3 } \cline { 2 - 3 } \begin{tabular}{c|c|c|c|c|} 
Potassium- \\
deficient \\
Fundulus
\end{tabular} & $\begin{array}{c}\text { Control } \\
\text { Fundulus }\end{array}$ & $\begin{array}{c}\text { Potassium- } \\
\text { deficient } \\
\text { Fundulus }\end{array}$ & $\begin{array}{c}\text { Control } \\
\text { Fundulus }\end{array}$ \\
\hline Range & $4.9-6.2$ & $2.7-3.3$ & $0.32-0.42$ & $0.030-0.035$ \\
\hline Mean & $5.4^{*}$ & $3.0^{*}$ & $0.38 \dagger$ & $0.033 \dagger$ \\
\hline No. of determinations & 13 & 17 & 4 & 3 \\
\hline
\end{tabular}

* Difference is significant at $0.1 \%$ level.

$\dagger$ Difference is significant at $1.0 \%$ level.

in the tissues of the potassium-deficient Fundulus appeared to be somewhat greater than in the controls (Table I), and (2) the concentration of lysine in the potassiumdeficient fish was much greater than in the controls, whereas the levels of histidine and arginine did not seem to be disproportionately large in the former. It was felt that the apparently greater total amino acid concentration observed in the potassium-deficient animals could not account for the extreme differences seen in the concentration of lysine.

Table I shows the values obtained from 17 determinations of the total amino acid concentration in the tissues of the controls and 13 determinations of the potassium-deficient fish. A certain amount of variation occurs in both cases. However, the extent of variation is relatively small when the difficulty of the method is considered. As was suggested by the semi-quantitative determination, a significantly greater concentration of free amino acids occurs in the muscle tissues of the potassium-deficient Fundulus. Although in the controls the concentration 
averages $3.0 \mathrm{mg}$. per gm. of tissue extracted, it reaches a level of $5.4 \mathrm{mg}$. per gm. in the potassium-deficient forms, i.e., a concentration 1.8 times as great.

Table I indicates the values obtained for lysine levels in control and potassiumdeficient Fundulus. Although only three determinations were made on the control animals and four on the potassium-deficient animals, the degree of variation was small in both instances and the differences observed in the lysine concentrations are regarded as significant. Indeed, the concentration of lysine in the skeletal muscle of the potassium-deficient forms appears to be more than 10 times as great as that of the control animals, whereas the total amino acid concentration is only 1.8 times as great.

\section{Discussion}

If animals are made deficient in potassium an influx of available extracellular cations would be expected in order to restore the cation-anion balance. In certain animals the lost potassium can be partly replaced by a gain in sodium. According to Cooke and his co-workers (1952) the remainder is replaced by an intracellular migration of protons, the result being the development of a plasma alkalosis. However, several investigators (Muntwyler, Griffen and Arends, 1953 ; Iacobellis, Muntwyler and Dodgen, 1956; Holliday and Segar, 1957) observed no plasma alkalosis in the potassium-deficient rat. Since Christensen, Riggs and Palatine (1952) showed that basic amino acids could act as intracellular cations, Eckel and his co-workers (1954) investigated the possibility of this being the case in potassium-deficient rats demonstrating no plasma alkalosis. Their results revealed that 8 to $40 \%$ of the intracellular metallic cation deficiency is replaced by lysine.

The results of this investigation show that, as in the case of the rat, the cation-anion imbalance appearing in the potassium-deficient Fundulus is partially overcome by an increase in the intracellular concentration of lysine. In Table I it can be seen that the concentration of lysine in the potassium-deficient Fundulus is approximately 10 times greater than in the controls. In terms of per cent of total amino acid concentration, the value for lysine is $1.1 \%$ in the case of the control animals and $7.0 \%$ in the potassium-deficient animals, an increase greater than $500 \%$.

The present results indicate that histidine and arginine contribute little to the increase in intracellular organic cation concentration in Fundulus. Furthermore no decrease was observed in aspartic and glutamic acids as Iacobellis, Muntwyler and Dodgen (1956) found with Wistar rats.

The total free amino acid concentration in the skeletal muscle tissue of potassium-deficient Fundulus is almost twice that of the controls (Table I). The observed increase may be the result of a decrease in the rate of nitrogen anabolism and perhaps the establishment of a negative nitrogen balance. Evidence that such is the case here is supplied by the work of Muntwyler, Griffen and Arends (1953) and Eckel, Norris and Pope (1958). Both groups reported decreased growth and a failure to maintain a proper nitrogen balance in the potassium-deficient rat. Conceivably in Fundulus as well as the rat an increased amount of free amino acids would be due to a failure of body protein synthesis and in certain cases (lysine) could serve to ameliorate a state of cation-anion imbalance by functioning as intracellular cations.

The fact that an identical device for combatting a loss of cellular potassium can be seen in animals as widely separated as mammals and fish suggests the 
interesting possibility of the universality of such a mechanism. It may be that a similar or perhaps identical mechanism accompanying a potassium deficiency can be found throughout the entire vertebrate group, indeed, perhaps in several phyla of the animal kingdom.

\section{SUMMARY}

1. The effect of a potassium deficiency on the free amino acids of the muscle tissues of Fundulus heteroclitus was investigated employing the method of quantitative paper chromatography.

2. An over-all increase in the total amino acid concentration was observed in the potassium-deficient fish amounting to 1.8 times that seen in the controls. A great increase in the concentration of lysine was also observed in the potassiumdeficient forms. In this case the concentration was about 10 times that of the controls.

3. It is therefore suggested that the mode of combating a potassium deficiency in the rat also exists in a fish. The interesting possibility that similar or perhaps identical mechanisms for lessening the effects of a potassium deficiency may be found throughout other representative vertebrate groups, as well as the invertebrates, offers a fruitful field for further comparative investigations.

\section{LITERATURE CITED}

Block, R., E. Durrum and G. Zweig, 1955. Paper Chromatography-Paper Electrophoresis. Academic Press, New York.

Christensen, H., H. Riggs and I. Palatine, 1952. Intense concentration of $\alpha, \gamma$ diaminobutyric acid. J. Biol. Chem., 198: 17-22.

Cooke, R., W. Segar, D. Cheek, F. Coville and D. Darrow, 1952. The extrarenal correction of alkalosis associated with potassium deficiency. J. Clin. Invest., 31: 798-805.

Eckel, R., C. Pope And J. Norris, 1954. Lysine as a muscle cation in potassium deficiency. Arch. Biochem. Biophys., 52: 293-294.

Eckel, R., J. Norris And C. Pope, 1958. Basic amino acids as intracellular cations in potassium deficiency. Amer. J. Physiol., 193: 644-652.

Giri, K., A. Radhakrishnan and C. Vaidyanathan, 1952. A simple paper chromatographic method for the study of transamination reactions. Nature, 170: 1025-1026.

Holliday, M., and W. Segar, 1957. The effect of low electrolyte feeding on the development of a potassium deficiency. Amer. J. Physiol., 191: 610-614.

Iacobellis, M., E. Muntwyler and C. Dodgen, 1956. Free amino acid patterns in certain tissues of potassium deficient rats. Amer. J. Physiol., 185: 275-278.

Iacobellis, M., G. Griffen and E. Muntwyler, 1957. Free amino acid patterns of certain tissues of potassium deficient dogs. Proc. Soc. Exp. Biol. Med., 96: 64-66.

Kay, R., D. Harris and C. Entenman, 1956. Quantification of the ninhydrin color reaction as applied to paper chromatography. Arch. Biochem. Biophys., 63: 14-25.

Muntwyler, E., G. E. Griffen and R. Arends, 1953. Muscle electrolyte composition and balances of nitrogen and potassium in potassium deficient rats. Amer. J. Physiol., 174: 283-288.

SzantaI, I., 1957. Behavior of amino acids developed with ninhydrin in an atmosphere of hydrogen chloride. Rev. Chim. (Bucharest), 8: 544. (C. A., 52: 2142a, 1958.) 


\section{$2 \mathrm{BHL}$ Biodiversity Heritage Library}

Hanlon, David P. 1960. "The effect of potassium deficiency on the free amino acid pattern of the muscle tissue of protein-maintained Fundulus heteroclitus." The Biological bulletin 118, 79-83.

https://doi.org/10.2307/1539058.

View This Item Online: https://www.biodiversitylibrary.org/item/110976

DOI: https://doi.org/10.2307/1539058

Permalink: https://www.biodiversitylibrary.org/partpdf/2123

\section{Holding Institution}

Smithsonian Libraries

\section{Sponsored by}

Biodiversity Heritage Library

\section{Copyright \& Reuse}

Copyright Status: In copyright. Digitized with the permission of the rights holder.

License: http://creativecommons.org/licenses/by-nc-sa/3.0/

Rights: https://biodiversitylibrary.org/permissions

This document was created from content at the Biodiversity Heritage Library, the world's largest open access digital library for biodiversity literature and archives. Visit BHL at https://www.biodiversitylibrary.org. 